\title{
Master of TESOL students' conceptions of assessment: questioning beliefs
}

Concepciones de evaluación del estudiantado de una maestría en

TESOL: una forma de cuestionar creencias

\author{
Volumen 21, Número 2 \\ Mayo - Agosto \\ pp. 1-29
}

Juan Diego Martínez Marín

Maria Camila Mejía Vélez 


\title{
Master of TESOL students' conceptions of assessment: questioning beliefs
}

\author{
Concepciones de evaluación del estudiantado de una maestría en TESOL:
} una forma de cuestionar creencias

\section{Juan Diego Martínez Marín Maria Camila Mejía Vélez²}

\begin{abstract}
The current descriptive study investigates the conceptions of a group students (pre-service and in-service teachers) enrolled in a Master of TESOL (Teaching English to Speakers of Other Languages) at La Trobe University, Australia, have of assessment in the context of English language teaching. This study was conducted in first place to address a gap in the literature about English teachers' conceptions of assessment, and I second place to explore the level of agreement among those conceptions and the type of assessment preferred by the participants. For this purpose, 26 active students in the course accepted the invitation to participate in the study and completed an online survey administered through Qualtrics Management Platform. This quantitative descriptive study done in 2020 used Survey as the research method since it promotes the collection of data to describe the research object. The quantitative data obtained through an online survey were summarized and graphed in tables with the objective of answering the research questions. The results showed that participants' understandings of assessment and forms of assessment were slightly inclined towards the use of summative assessment rather than formative. In contrast, their conceptions of assessment purposes and principles were inclined towards formative assessment features. All in all, it could be said that even though these participants seemed to cope more with summative assessment, they favoured formative purposes and principles of assessment. This suggests that respondents' summative views of assessment in the use of types and forms of assessment are potentially affected by institutional demands, and do not entirely reflect the respondents' assessment understandings.
\end{abstract}

Keywords: assessment, formative evaluation, evaluation methods, second language instruction

Resumen: Este estudio descriptivo investiga las concepciones sobre evaluación de un grupo de estudiantes matriculado en la maestría en Enseñanza del Inglés para hablantes de otras lenguas (TESOL por sus siglas en inglés) en la Universidad de La Trobe, Australia. Este estudio fue desarrollado en primer lugar, para fortalecer la producción científica sobre las concepciones de evaluación de docentes de inglés, ya que esta es limitada, y, en segundo lugar, para explorar el nivel de concordancia entre esas concepciones y el tipo de evaluación preferida. Para ello, 26 estudiantes activos aceptaron la invitación a participar en el estudio y completaron una encuesta en línea administrada a través de Qualtrics Management Platform. Este estudio cuantitativo descriptivo llevado a cabo en el 2020 usó la Encuesta como método de investigación, ya que ésta promueve la recopilación de datos para describir el objeto de investigación. Los datos cuantitativos obtenidos a través de una encuesta en línea, se resumieron y graficaron en tablas con el objetivo de responder a las preguntas de investigación. Los resultados mostraron que la comprensión de la evaluación y las formas de evaluación de las personas participantes se inclinaban ligeramente hacia el uso de la evaluación sumativa en lugar de la formativa. En contraste, las concepciones de los propósitos y principios se inclinaron hacia la evaluación formativa. Se podría decir que, aunque las personas participantes tenían más tendencia hacia la evaluación sumativa, favorecían los propósitos y los principios de la evaluación formativa, lo que podría indicar que su inclinación se debe a las demandas institucionales y no refleja por completo sus concepciones.

Palabras clave: evaluación, evaluación formativa, métodos de evaluación, enseñanza de una segunda lengua

\begin{abstract}
${ }^{1}$ Profesor de la Universidad Pontificia Bolivariana, Medellín, Antioquia, Colombia. Magister en TESOL de La Trobe University (Australia) y candidato a Doctor de la Universidad Nacional de Colombia, Medellín, Colombia. Dirección electrónica: juandi.martinez@upb.edu.co Orcid https://orcid.org/00000003-0844-7889

2 Profesora de la Universidad de Medellín, Medellín, Antioquia, Colombia. Licenciada en Español-Inglés de la Universidad Pontificia Bolivariana, Medellín, Colombia, y Magister en TESOL de La Trobe University (Australia). Dirección electrónica: mariacamila.mejiavelez@hotmail.com Orcid https://orcid.org/0000-0002-2027-7408
\end{abstract}

Artículo recibido: 17 de noviembre, 2020

Enviado a corrección: 9 de marzo, 2021

Aprobado: 19 de abril, 2021 


\section{Introduction}

Assessment plays an essential role in the language learning and teaching processes since it links educational policies, the curriculum, syllabus, and approaches, as well as the classroom tasks and activities, and the students' performance and competences (Cheng \& Fox, 2017; Tsagari et al., 2018). Hence, performing any assessment process can guide teachers to identify students' learning strengths and difficulties, so teachers can re-design and re-adapt meaningful and contextualized communicative tasks and activities to promote students' learning agency (Everhard, \& L. Murphy, 2015). In addition, assessment helps teachers to question whether their teaching strategies, techniques and instruments are suitable for the current language users and contexts, to reflect on their practices and make more valid and reliable decisions (Murphy, 2015). This requires teachers to consider the students' features (Earl \& Giles, 2011), their language competence (Council of Europe, 2001), and the classroom contexts and needs.

From this complex panorama, the understanding English Language (EL) teachers have about assessment could be affected by diverse factors. These might include but are not limited to EL teaching and learning theories (Richards \& Rodgers, 2015); the relationship between teaching and learning (Case, 2015); the language curricula (Macalister \& Nation, 2011); the way the assessment concept is associated with verbs like grading, promoting, evaluating, measuring, judging, valuing, among others (Álvarez, 2008; Brown \& Remesal, 2012); the use of tests (Bachman \& Palmer, 2010; Shohamy, 2007), and the increase in testing and assessment responsibilities that lie with teachers (Scarino, 2013). Such factors, plus the lack of knowledge about fundamental theories of assessment among language teachers, may affect the validity and reliability of their assessment practices (Deluca, Lapointe-Mcewan \& Luhanga, 2016; Scarino, 2017).

From this perspective, it becomes paramount to identify and describe EL teachers' conceptions of assessment. This might enable them to reflect and evaluate their understandings of assessment, so they can reconceptualise and re-adapt them if necessary, in alignment with current theories, practices and environments of English language teaching and learning (Brindley, 2001; Scarino, 2017). This reconceptualization and re-adaptation should aim to advocate practices that acknowledge not only summative assessment conceptions but also formative. In this way, EL teachers can implement tasks that promote appropriate language learning skills and strategies, as well as being able to value students' performance and achievements in context (Brown, Lake \& Matters, 2011; Scarino, 2013; 2017). 


\subsection{Research focus}

For this study, the research focus is Master of TESOL (Teaching English to Speakers of Other Languages) students' conceptions of assessment. In general terms, conceptions are understood as a set of mental meanings that are built throughout different constructs, concepts, mental images, intentions, knowledge and contexts (Brown et al. 2011; Opre, 2015). For this research, EL teachers' conceptions of assessment are seen as the way they understand assessment according to their teaching beliefs, practices and contexts.

\subsection{Research aims}

The main purpose of this research is to provide a descriptive insight about how Master of TESOL students understand assessment when teaching English, and how these conceptions are linked to other aspects of assessment such as its purposes, principles, types and forms. This study also discusses whether research participants have similar conceptions and use similar types of assessment, in order to create an overview of what they understand by assessment. The main question to be answered is: What are Master of TESOL students' conceptions of assessment when teaching English? The secondary questions are: What is the most common type of assessment Master of TESOL students prefer? and What is the level of agreement regarding Master of TESOL students' conceptions of assessment in their teaching practices?

\section{Literature review}

\subsection{Conceptions of assessment}

In published research literature, the word conceptions has been understood from multiple views which are interconnected and helped the researchers to frame the conceptions of assessment. Based on his empirical research, Brown (2008) acknowledged that the word conception as a cognitive structure embraces how "a teacher views, interprets and interacts with the teaching environment" (p. 2); it is an idea that is circumscribed in belief systems and clusters.

Brown et al. (2011) have said that conceptions encompass the way teachers think and perform in relation to their teaching and learning beliefs, contexts and practices. For Opre (2015), the definition of conceptions is related to the integration of teachers' knowledge, beliefs and practices. Following these views, for this research, EL teachers' conceptions of 
assessment are understood as a set of teaching beliefs about assessment theory and assessment practices.

In order to understand the implications and nature of teachers' conceptions of assessment, it is important to introduce what is understood in this study by language assessment. Bachman \& Palmer (2010), Brown \& Abeywickrama (2019), Frank (2012), McNamara \& Roever (2006), Roever (2011) and Shohamy (2007) considered that language assessment underpins language teaching and learning processes. On the one hand, it is intrinsically related to elements that are part of the language teaching environment such as language policies, curriculum, approaches and classroom practices. On the other hand, it helps teachers to develop their teaching strategies, practices and instruments (Brown \& Abeywickrama, 2019). Earl \& Giles (2011) argued that assessment is also involved in identifying students' learning difficulties to mediate them, and strengths to enhance them.

Despite these theoretical perspectives offering diverse views and considerations of language assessment, some scholars such as Leung \& Lewkowicz (2010), Purpura (2016) and Scarino (2013) have stated that language assessment conceptions can be modified by social, cultural, economic and political practices teachers show when teaching. That is why language assessment has acquired different connotations among the educational community, related to words such as grading, promoting, evaluating, measuring, judging, valuing, among others (Álvarez, 2008).

\subsection{Teachers' conceptions of assessment}

In a research done in Queensland, Australia, Brown et al. (2011), using a qualitative model of conceptions of assessment, stated that teachers' understandings are directly influenced by the relationship between educational contexts and policies. Therefore, they suggested that teachers' conceptions of assessment could be analysed from three different perspectives. One dealt with assessment as a way to improve teaching and learning, the other with assessment as a way to make schools, teachers and students accountable, and the last with assessment as an irrelevant element in the educational process. The results of the study demonstrated that the educational policies in context have a direct impact on how teachers understand assessment, which at the same time affects their assessment practices.

In a research study done in some Western (represented by the US, the UK, New Zealand, Australia and Finland) and Eastern (represented by Hong Kong and Singapore) countries, Azis (2012) explored teachers' conceptions of assessment and found that these conceptions are 
aligned with contextual educational goals. In Western countries, she asserted that teachers favoured formative assessment and alternative instruments. Accordingly, pedagogical strategies such as self-assessment, peer-assessment, providing feedback or using problemsolving tasks were favoured over summative assessment and traditional instruments such as standardised tests. In Hong Kong and Singapore, Azis (2012) noted that although teachers partially acknowledged that the use of assessment might promote students' learning, they preferred summative assessment and traditional instruments like high-stakes tests.

In Egypt, Gebril (2017) researched EL teachers' conceptions of assessment with 170 preservice and in-service teachers. He found that both groups of teachers had inconsistent beliefs about language assessment. In-service English teachers preferred a combination of formative and summative assessment practices, while pre-service English teachers favoured summative assessment since it is aligned with their contextual, educational, economic and cultural demands. Both groups of teachers expressed that tests and their results substantially indicated language learning progress, how teacher training courses could be improved, and how resources must be invested to effectively implement English language assessment policies in the country.

In another research project conducted in Ecuador, South America, Brown \& Remesal (2017) used two qualitative models to determine the level of agreement among 563 Ecuadorian teachers on assessment conceptions. They established that the educational policies constrained teachers' assessment practices, but did not necessarily reflect the ones they endorsed, nor their assessment beliefs. From this perspective, some schools and teachers from Ecuador demonstrated a certain level of awareness about the importance of formative assessment practices that could contribute to the improvement of education.

\subsection{Purposes of assessment}

In terms of purposes of assessment Earl (2013) and Earl \& Giles (2011) has become particularly influential, since they coined the terms assessment of, for, as and in learning, as a way of framing the purposes of assessment from both formative and summative views. On the one hand, Earl (2013) stated that assessment of learning comprises summative assessment purposes such as testing, grading, marking or measuring. In this sense, assessment of learning deals with the formal and numerical identification of learning outcomes.

On the other hand, Earl \& Giles (2011) described assessment for learning as an ongoing process to gather information about the learners' performance. Unlike assessment of learning, 
this purpose (for learning) is associated with assessment such as peer-assessment, heteroassessment, self-assessment, co-assessment or feedback that favours the valuation of students' performance rather than the measurement of their achievement. In respect to assessment as learning, these scholars highlighted that this is seen as one of the most important purposes, since students have an active role in their learning process, working as their own assessors based on valid, negotiated and reliable data that guide them to value and judge their performance. Lastly, assessment in learning is linked to providing students with authentic learning experiences, which allows them to connect in-classroom tasks with outsideclassroom realities. This purpose (in learning) aims to position assessment as a strategy to mobilise and connect the aspects involved in the teaching process such as approaches, curricula, syllabi or educational resources, and ensure these are aligned with the students' needs and learning goals.

\subsection{Assessment principles}

The highly influential Assessment Reform Group (ARG) brought together ten assessment principles $^{3}$ in 2002 that not only addressed the necessity of advocating learning as a lifelong condition, but also demonstrated how assessment can affect learning. The principle of assessment as part of effective planning has to do with how planning can give teachers and students possibilities to identify learning progress in relation to set goals. This can enable students and teachers to mediate potential difficulties by adjusting assessment tasks when necessary, establishing strategies for improvement and providing feedback to guarantee that students continue to advance towards the learning outcomes. The principle of assessment focused on how students learn considers the relevance of being conscious not only of what will be learnt but also the means and strategies to learn, in other words, how learning can occur.

The principle of assessment as central to classroom practice acknowledges that everything that happens in the classroom is deeply bonded with assessment. This not only engages teachers and students in ongoing reflections and negotiations, but also places assessment as a process that can link the curriculum and approaches with activities and tasks in situ. The principle of assessment as a key professional skill reinforces the idea that

\footnotetext{
3 These principles state that assessment "is part of effective planning, focuses on how students learn, is central to classroom practice, is a key professional skill, is sensitive and constructive, fosters motivation, promotes understanding of goals and criteria, helps learners know how to improve, develops the capacity for self-assessment, recognises all educational achievement." (ARG, 2002, p. 2)
} 
assessment needs to be valued as a paramount knowledge and skill in teachers' professional development. The principle of assessment as a sensitive and constructive process refers to the effect assessment can have emotionally on learners, which might be either negative or positive. The principle of assessment to foster motivation stresses the relevance of preserving and promoting students' motivation. Results, achievements and any progress in the learning process might be used as resources to engage students and increase confidence, through different assessment techniques.

The principle of assessment committed to the understanding of goals and criteria argues that for meaningful learning to happen, students need to be aware of the outcomes they are expected to achieve in the process. The principle of assessment to help learners know how to improve states teachers need to offer students information and strategies that allow them to improve and set their learning strategies and styles. The principle of assessment to cultivate the capacity for self-assessment focuses on the development of students' learning autonomy. It sets a great challenge for teachers since they need to advocate independent learning by carefully planning assessment practices. Lastly, the principle of assessment to recognise all educational achievement states that teachers' comments and suggestions about student performance should not only focus on students' difficulties but assets in and outside the classroom.

\subsection{Types and forms of assessment}

\subsubsection{Formative and summative types of assessment}

Scholars (Bennett, 2010; Dixson \& Worrell, 2016; Taras, 2005) have described types of assessment as the techniques or procedures used by teachers to undertake assessment. In the words of Taras (2005), types of assessment respond to "the mechanics or steps required to effectuate a judgement" (p. 467). These help teachers to intervene in the learning process, measure or value students' progress and determine how to implement resources.

Following the ideas of various scholars (Bennett, 2010; Council of Europe, 2001; Dixson \& Worrell, 2016; Jorba \& Sanmartí, 2000; Taras, 2005), each type of assessment maintains a close relationship with the purposes of assessment from a formative or summative perspective (Barnes, Fives \& Dacey, 2017; Earl, 2013; Ear \& Giles, 2011). Bearing this in mind, types of assessment can focus on either formative or summative practices, depending on the expected learning outcomes. 
According to Black \& Wiliam (2010), Dixson \& Worrell (2016), and Jorba \& Sanmartí (2000), each type of assessment has specific features. On the one hand, formative assessment types deal with ongoing activities and tasks that provide evidence of students' performance, which is used to enhance strengths or mediate with potential difficulties. Formative assessment types promote active learning roles and encompass collaborative work between teachers and students in order to make meaning, as well as determine where learners are in relation to the learning outcomes. On the other hand, summative assessment types have to do with a process in which students' achievements, skills and competences are measured systematically and quantitatively (Bennett, 2010; Dixson \& Worrell, 2016). Summative assessment types are mostly performed at the end of a teaching or study term through traditional forms of assessment such as standardised tests, exams, quizzes or workshops, which have set answers and aim to inform through grades if a student has succeeded.

\subsubsection{Forms of assessment}

In accordance with Brown \& Abeywickrama (2019), forms of assessment can be divided into alternative and traditional instruments. Alternative instruments are associated with formative assessment and those types that promote and value students' learning capacities, competences, skills, styles and strategies. These include but are not limited to portfolios, journals, essays, presentations, role plays or WebQuests. Alternative instruments are intended to be implemented as an ongoing process and not in a specific stage of the learning process, which implies that they are untimed and have free responses aligned with task criteria. In this way, students might find multiple ways to address the communicative activities and tasks.

On the contrary, traditional instruments are related to summative assessment types, in which most of the forms aim to measure students' skills, achievements or knowledge (Cornelius, 2014). These traditional forms of assessment are usually called hard instruments, since they include most types of paper-based or computer-based instruments that require one answer. These include standardized tests, quizzes and any other similar instrument that uses expected answer techniques such as multiple-choice, true-false, filling the gaps or matching exercises (Bachman \& Palmer, 2010).

Following the ideas of Bachman \& Palmer (2010), Brown \& Abeywickrama (2019) and Roever (2011), alternative and traditional forms of assessment are structured differently. Alternative instruments comprehend multiple sub-tasks that happen in different moments of the learning process, whose purpose is to help students to achieve the learning outcomes of the 
main task. Alternative assessment forms usually require an alternate resource to assist teachers in the valuation of students' performance, such as a rubric. Conversely, traditional instruments comprehend only one main task such as completion of a test or workshop, which happens in a specific moment in the students' learning processes. These forms of assessment do not usually require an alternate resource to assess, since they have fixed answers.

\section{Methodology}

\subsection{Research design}

This cross-sectional study, done in 2020, employs Survey as a research methodology (Cohen, Manion \& Morrison, 2018; Creswell, 2018; De Leeuw, Hox \& Dillman, 2008; Fowler, 2014; Richards \& Rodgers, 2015). This descriptive method is used to gather information systematically from a sample of respondents with the purpose of obtaining valid data that could identify, describe or determine a specific group's opinion on a specific topic. Cohen et al. (2018) argue that survey methodology explores and confirms the research object(s) and/or subject(s) through a scanning process where the qualitative and quantitative data collected are compared and contrasted. This produces some favourable characteristics such as one-off data gathering, characterizing the target population, offering inferential information, and standardizing information for all respondents.

\subsection{Survey respondents}

The recruitment of the respondents followed several steps. First, we contacted the Course Coordinator and Subject Coordinators, who were teaching during the semester in the Master of TESOL course at La Trobe University, Au. We requested permission and collaboration to upload a video invitation and a link to ask Master of TESOL students to complete the online questionnaire. Once having the professors' approval, an invitation and the link were uploaded to the Learning Management System (LMS) of three subjects in the Master of TESOL course. That invitation introduced the title, the purposes and the methodology of the project, as well as the content of the questionnaire. It also indicated that this project had the approval of the Human Ethics Committee of the University and that participation was completely voluntary. Finally, the potential respondents were told that under the video invitation there was a link to the online questionnaire. The link contained the Participant Information Statement (PIS) and the questions to be answered. In total, 26 respondents completed the questionnaire. 
The respondents to the online questionnaire were Master of TESOL students, whose enrolment was active at the time of their participation. From a total of 33 students, 26 responses were received, representing a response rate of 78.7 per cent. The majority of respondents were female and about one third were male. Nearly 70 per cent held bachelor's degrees in fields related to English language, English language teaching, educational leadership and management, and education. Only three respondents held bachelor's degrees unrelated to language teaching, namely in translation, economics and biochemistry. Nearly one fifth held masters' degrees; however, the areas were not indicated. Their educational qualifications were obtained in different parts of the world such as Australia, Canada, China, Colombia, India, Nepal, Pakistan, Sir Lanka and Vietnam.

Just over 80 per cent of respondents had between one to five years of English teaching experience; 15.3 per cent between 6 and 10 years; and 3.8 per cent over 10 years. In terms of their employment, the respondents had worked in secondary education (30.9\%), primary (25.4\%) and language centres (25.4\%). During their teaching experience, respondents affirmed they had mostly taught English as a second language (38.3\%) and as a foreign language (34\%). However, some had taught English for specific purposes (17\%) and as an additional language (10\%). The most frequent English teaching approach that emerged in the respondents' answers was the Communicative (80\%), while other approaches such as Audiolingual (8\%), Blended Learning (4\%), Grammar Translation (45\%), Total Physical Response (4\%), and Task-based (4\%) were less frequent.

\subsection{Data collection}

The research instrument for data collection was an online questionnaire (See Appendix A) administered through Qualtrics Management Platform (https://www.qualtrics.com/au/). The instrument was designed to obtain descriptive information about the conceptions of assessment held by Master of TESOL students. A cross-sectional survey design was selected to show current attitudes, beliefs and practices of the selected sample (Creswell, 2018). The questions were formulated considering the research purposes and questions, and the concepts analysed in the literature review. The final version of the online questionnaire asked respondents to describe their understanding of assessment using 15 questions.

To improve and validate the survey instrument, it was reviewed by two professors from the University's School of Education to assess the design, content, type and amount of questions, scales, and linguistic appropriateness for the study. The survey instrument was also 
analysed by four in-service English language teachers and one Master of TESOL student to obtain feedback on the instructions, questions and items. This feedback allowed the researchers to ensure the instrument provided an adequate representation of the research phenomenon (EL teachers' conceptions of assessment).

\subsection{Data analysis}

The data analysis procedure occurred as follows. First, the data was exported from Qualtrics Management Platform into a Platform into a spreadsheet file Microsoft Office Excel. The quantitative data were summarized and graphed through percentages and frequencies. The qualitative data were summarised through analysis categories that emerged from the frequency of the respondents' answers.

\section{Results}

\subsection{Understandings of assessment}

Question 10 (Table 1) asked respondents to describe in their words what they understood by assessment. In order to analyse and describe the responses, they were coded and grouped based on their frequency by focusing on the content words of the respondents' answers. The word Procedures on the left-hand column of Table 1 refers to the name respondents gave to the word assessment. The word Actions relates to the activities respondents said they used to develop assessment, and the word Objectives makes reference to the element that assessed according to the respondents' answers. In addition, depending on the assessment actions, responses were divided into formative and summative assessment since these perspectives were used to frame teachers' conceptions of assessment as discussed in section 2. 
Table 1

Melbourne, Australia: frequency of students' understandings of assessment. 2020

\begin{tabular}{|c|c|c|c|}
\hline \multicolumn{4}{|c|}{ Formative assessment } \\
\hline Procedures & Actions & Objectives & Frequency \\
\hline Process & to improve & students' learning processes & 4 \\
\hline Way & to promote & students' language competences & 2 \\
\hline A method & to understand & students' language learning & 3 \\
\hline Strategy & to support & students' learning activities & 2 \\
\hline Activity & to develop & students' learning performance & 1 \\
\hline Total & & & 12 \\
\hline \multicolumn{4}{|c|}{ Summative assessment } \\
\hline Process & to test & students' communicative skills & 1 \\
\hline Way & to mark & students' linguistic achievements & 5 \\
\hline A method & to measure & students' learning knowledge & 6 \\
\hline Strategy & to evaluate & students' English level & 2 \\
\hline Total & & & 14 \\
\hline
\end{tabular}

Source: compiled by the author based on data gathered through Master of TESOL students' answers, 2020

As shown in Table 1, respondents associated assessment with procedures that have different actions and objectives. In terms of the procedures and considering responses that were categorised as both formative and summative, words such as process (5), way (7), method (9), strategy (4) and activity (1) were used. This suggested that the respondents might understand assessment as a series of actions that allowed them to achieve particular goals. The actions indicated, on the one hand, that relating assessment with words such as improve (4), promote (2), understand (3), support (2) and develop (1), might reflect an understanding focused on valuing students' language learning processes, activities and performances (formative assessment) rather than on measuring them. On the other hand, just over half of the respondents (53.8\%) associated assessment actions with words such as test (1), mark (5), measure (6) and evaluate (2) students' linguistic knowledge and levels, which suggested they might be inclined to summative assessment practices.

Question 11 (Table 2) examined agreement or disagreement with conceptions of assessment that have been identified by a range of scholars in the field of assessment. These conceptions are represented by Statements as shown in Table 2, and the level of agreement is expressed in frequencies and percentages. 


\subsection{Conceptions of Assessment}

Table 2

Melbourne, Australia: frequency and percentages of students' conceptions of assessment. 2020

\begin{tabular}{|c|c|c|c|c|c|c|}
\hline Q11 & Statements & $\begin{array}{l}\text { Strongly } \\
\text { disagree }\end{array}$ & Disagree & Agree & $\begin{array}{l}\text { Strongl } \\
\text { y agree }\end{array}$ & Total \\
\hline a. & $\begin{array}{l}\text { assessment provides information on } \\
\text { how much students have learned }\end{array}$ & $\begin{array}{c}3 \\
11.54 \%\end{array}$ & $\begin{array}{c}5 \\
19.23 \%\end{array}$ & $\begin{array}{c}7 \\
26.92 \%\end{array}$ & $\begin{array}{c}11 \\
42.31 \%\end{array}$ & 26 \\
\hline b. & assessment must be done daily & $\begin{array}{c}8 \\
30.77 \%\end{array}$ & $\begin{array}{c}8 \\
30.77 \%\end{array}$ & $\begin{array}{c}7 \\
26.92 \%\end{array}$ & $\begin{array}{c}3 \\
11.54 \%\end{array}$ & 26 \\
\hline c. & $\begin{array}{l}\text { assessment must be done through } \\
\text { written tests, exams, quizzes, etc. }\end{array}$ & $\begin{array}{c}4 \\
15.38 \%\end{array}$ & $\begin{array}{c}7 \\
26.92 \% \\
\end{array}$ & $\begin{array}{c}5 \\
19.23 \% \\
\end{array}$ & $\begin{array}{c}10 \\
38.46 \%\end{array}$ & 26 \\
\hline d. & $\begin{array}{l}\text { assessment must be done through } \\
\text { portfolios, journals, presentations, etc. }\end{array}$ & $\begin{array}{c}4 \\
15.38 \%\end{array}$ & $\begin{array}{c}8 \\
30.77 \%\end{array}$ & $\begin{array}{c}11 \\
42.31 \%\end{array}$ & $\begin{array}{c}3 \\
11.54 \%\end{array}$ & 26 \\
\hline e. & $\begin{array}{l}\text { assessment must be done only by the } \\
\text { teacher }\end{array}$ & $\begin{array}{c}2 \\
7.69 \%\end{array}$ & $\begin{array}{c}11 \\
42.31 \%\end{array}$ & $\begin{array}{c}7 \\
26.92 \%\end{array}$ & $\begin{array}{c}6 \\
23.08 \%\end{array}$ & 26 \\
\hline f. & $\begin{array}{l}\text { assessment must be reported to } \\
\text { students orally }\end{array}$ & $\begin{array}{c}2 \\
7.69 \%\end{array}$ & $\begin{array}{c}14 \\
53.85 \%\end{array}$ & $\begin{array}{c}8 \\
30.77 \%\end{array}$ & $\begin{array}{c}2 \\
7.69 \%\end{array}$ & 26 \\
\hline g. & $\begin{array}{l}\text { assessment must be reported to } \\
\text { students in a written way }\end{array}$ & $\begin{array}{c}2 \\
7.69 \% \\
\end{array}$ & $\begin{array}{c}7 \\
26.92 \% \\
\end{array}$ & $\begin{array}{c}12 \\
46.15 \% \\
\end{array}$ & $\begin{array}{c}5 \\
19.24 \% \\
\end{array}$ & 26 \\
\hline h. & $\begin{array}{l}\text { numbers and/or letters can represent } \\
\text { how much students know about the } \\
\text { language }\end{array}$ & $\begin{array}{c}4 \\
15.38 \%\end{array}$ & $\begin{array}{c}8 \\
30.77 \%\end{array}$ & $\begin{array}{c}6 \\
23.08 \%\end{array}$ & $\begin{array}{c}8 \\
30.77 \%\end{array}$ & 26 \\
\hline i. & $\begin{array}{l}\text { assessment helps students to improve } \\
\text { their language learning strategies and } \\
\text { skills }\end{array}$ & $\begin{array}{c}1 \\
3.85 \%\end{array}$ & $\begin{array}{c}4 \\
15.38 \%\end{array}$ & $\begin{array}{c}15 \\
57.69 \%\end{array}$ & $\begin{array}{c}6 \\
23.08 \%\end{array}$ & 26 \\
\hline
\end{tabular}

Source: compiled by the author based on data gathered through Master of TESOL students' answers, 2020

As seen in Table 2, a much larger percentage of respondents Strongly agreed (42.31\%) than Strongly disagreed (11.54\%) with statement 11a: "assessment provides information on how much students have learned". The level of disagreement (30.77\%) and strong disagreement $(30.77 \%)$ in statement $11 \mathrm{~b}$ was the same. Considered together, they indicated that over 60 per cent of respondents $(\mathrm{N}-16)$ stated that assessment must not be done daily.

In statement 11c, 19.23 per cent of respondents agreed that "assessment must be done through written tests, exams, quizzes, etc." and 38.46 per cent strongly agreed, which indicated that almost 60 per cent of respondents (57.69\%) agreed. In statement 11d, 42.31 per cent agreed that "assessment must be done through portfolios, journals, presentations, etc.", and 11.54 per cent strongly agreed, representing over half $(53.85 \%)$ of responses. The percentages of agreement in statements $11 \mathrm{c}$ and 11d indicated a slight tendency to use traditional (written tests, exams, quizzes, etc.) rather than alternative forms of assessment (portfolios, journals, presentations, etc.). 
Table 2. shows that the Disagree category produced the most responses for item 11e, with 42.31 per cent disagreeing that "assessment must be done only by the teacher", while 26.92 per cent agreed. Over 60 per cent of respondents strongly disagreed (7.69\%) or disagreed (53.85\%) that "assessment must be reported to students orally" (11f); while nearly half agreed on reporting assessment in a written way $(11 \mathrm{~g})(46.15 \%)$. Together, the categories of Agree and Strongly agree in statement $11 \mathrm{~h}$ indicated that slightly more than half of the respondents (53.85\%) agreed that "numbers and/or letters can represent how much students know about the language." Lastly, the majority of respondents (57.69\%) agreed with the idea that assessment helps students to improve their language learning (11i).

\subsection{Assessment purposes}

Question 12 (Table 3) asked respondents to what extent they agreed with statements related to assessment purposes. The level of agreement of respondents with these statements is presented through frequencies and percentages.

Table 3

Melbourne, Australia: frequency and percentages of students' Understandings of Assessment Purposes. 2020

\begin{tabular}{|c|l|c|c|c|c|c|}
\hline Q12 & \multicolumn{1}{|c|}{ Statements } & $\begin{array}{l}\text { Strongly } \\
\text { disagree }\end{array}$ & Disagree & Agree & $\begin{array}{c}\text { Strongly } \\
\text { agree }\end{array}$ & Total \\
\hline a. & $\begin{array}{l}\text { assessment outcomes can help } \\
\text { students to improve their language } \\
\text { level }\end{array}$ & $\begin{array}{c}3 \\
11.54 \%\end{array}$ & $\begin{array}{c}3 \\
11.54 \%\end{array}$ & $\begin{array}{c}9 \\
34.62 \%\end{array}$ & $\begin{array}{c}11 \\
42.30 \%\end{array}$ & 26 \\
\hline b. & $\begin{array}{l}\text { self-assessment is a complementary } \\
\text { part of assessment }\end{array}$ & $\begin{array}{c}4 \\
15.38 \%\end{array}$ & $\begin{array}{c}6 \\
23.08 \%\end{array}$ & $\begin{array}{c}8 \\
30.77 \%\end{array}$ & $\begin{array}{c}8 \\
30.77 \%\end{array}$ & 26 \\
\hline c. & $\begin{array}{l}\text { assessment must be a process to } \\
\text { gather information about students' } \\
\text { learning achievements }\end{array}$ & $\begin{array}{c}2 \\
7.69 \%\end{array}$ & $\begin{array}{c}3 \\
11.54 \%\end{array}$ & $42.31 \%$ & $38.46 \%$ & 26 \\
\hline d. & $\begin{array}{l}\text { assessment must integrate the } \\
\text { language learning and teaching } \\
\text { processes }\end{array}$ & $\begin{array}{c}2 \\
7.69 \%\end{array}$ & $\begin{array}{l}3 \\
11.54 \%\end{array}$ & $53.85 \%$ & $26.92 \%$ & 26 \\
\hline
\end{tabular}

Source: compiled by the author based on data gathered through Master of TESOL students' answers, 2020

For item 12a, Table 3 shows that respondents strongly agreed (42.31\%) more than strongly disagreed $(11.54 \%)$ that "assessment outcomes can help students to improve their language level". More than 60 per cent of respondents agreed or strongly agreed that "selfassessment is a complementary part of assessment" (12b) (30.77\%; 30.77\% respectively). Likewise, there was far more agreement (42.31\%) and strong agreement (38.46\%) than disagreement $(11.54 \%)$ and strong disagreement $(7.69 \%)$ with statement $12 \mathrm{c}$ : "assessment 
must be a process to gather information about students' learning achievements". Just over half of those surveyed (53.85\%) agreed or agreed strongly (26.92\%) that "assessment must integrate the language learning and teaching processes" (12d), while a minority disagreed (7.69\%).

\subsection{Assessment principles}

Question 13 (Table 4) explored the level of agreement of respondents with statements related to assessment principles. Their agreement with each of these statements is presented through frequencies and percentages.

Table 4

Melbourne, Australia: frequency and percentages of students' understandings of assessment

\begin{tabular}{|c|c|c|c|c|c|c|}
\hline Q13 & Statements & $\begin{array}{l}\text { Strongly } \\
\text { disagree }\end{array}$ & $\begin{array}{c}\text { Disagre } \\
\mathbf{e}\end{array}$ & Agree & $\begin{array}{l}\text { Strongly } \\
\text { agree }\end{array}$ & Total \\
\hline a. & $\begin{array}{l}\text { assessment must be done through } \\
\text { problem-solving activities }\end{array}$ & $\begin{array}{c}3 \\
11.54 \%\end{array}$ & $\begin{array}{c}6 \\
23.08 \%\end{array}$ & $\begin{array}{c}12 \\
46.15 \%\end{array}$ & $\begin{array}{c}5 \\
19.23 \%\end{array}$ & 26 \\
\hline b. & $\begin{array}{l}\text { assessment works as a teaching } \\
\text { strategy planned in the syllabus }\end{array}$ & $\begin{array}{c}2 \\
7.69 \%\end{array}$ & $\begin{array}{c}7 \\
26.92 \%\end{array}$ & $\begin{array}{c}11 \\
42.31 \%\end{array}$ & $\begin{array}{c}6 \\
23.08 \%\end{array}$ & 26 \\
\hline c. & $\begin{array}{l}\text { assessment has an impact on students' } \\
\text { learning motivation }\end{array}$ & $\begin{array}{c}1 \\
3.84 \%\end{array}$ & $\begin{array}{c}6 \\
23.08 \%\end{array}$ & $\begin{array}{c}9 \\
34.62 \%\end{array}$ & $\begin{array}{c}10 \\
38.46 \%\end{array}$ & 26 \\
\hline d. & $\begin{array}{l}\text { teachers must make explicit the } \\
\text { assessment objectives throughout the } \\
\text { subject }\end{array}$ & $\begin{array}{c}2 \\
7.69 \%\end{array}$ & $\begin{array}{l}3 \\
11.54 \%\end{array}$ & $\begin{array}{c}14 \\
53.85 \%\end{array}$ & $\begin{array}{c}7 \\
26.92 \%\end{array}$ & 26 \\
\hline e. & $\begin{array}{l}\text { students must participate in the design } \\
\text { of the assessment process in every } \\
\text { subject }\end{array}$ & $\begin{array}{c}10 \\
38.46 \%\end{array}$ & $\begin{array}{c}9 \\
34.62 \%\end{array}$ & $\begin{array}{c}6 \\
23.08 \%\end{array}$ & $\begin{array}{c}1 \\
3.84 \%\end{array}$ & 26 \\
\hline
\end{tabular}

Source: compiled by the author based on data gathered through Master of TESOL students' answers, 2020

The results in Table 4 show that for 13a, more respondents agreed (46.15\%) than disagreed $(26.08 \%)$ that "assessment must be done through problem-solving activities". Over 60 per cent of respondents agreed or strongly agreed that "assessment works as a teaching strategy planned in the syllabus" (13b) (42.31\%; 23.08\% respectively). Responses to statement 13c, "assessment has an impact on students' learning motivation", indicated that less than five per cent $(3.85 \%)$ strongly disagreed, while just under 40 per cent strongly agreed. In regard to $13 d$, over half $(53.85 \%)$ of the respondents agreed that "teachers must make explicit the assessment objectives throughout the subject". Considering the disagreement categories, strong disagreement and disagreement accounted for over 70 per cent of responses to the statement "students must participate in the design of the assessment process in every subject" (13e) $(38.46 \%$; 34.62\% respectively). 


\subsection{Types of assessment}

Question 14 (Table 5) asked respondents to what extent they agreed with statements related to types of assessment. The level of agreement of respondents with these statements is presented through frequencies and percentages.

Table 5

Melbourne, Australia: frequency and percentages of students' understandings of types of assessment. 2020

\begin{tabular}{|c|c|c|c|c|c|c|}
\hline Q14 & Statement & $\begin{array}{l}\text { Definitely } \\
\text { not }\end{array}$ & $\begin{array}{l}\text { Probably } \\
\text { not }\end{array}$ & $\begin{array}{c}\text { Very } \\
\text { probably }\end{array}$ & Definitely & Total \\
\hline a. & $\begin{array}{l}\text { assessment must be developed } \\
\text { according to the educational } \\
\text { institution's curriculum }\end{array}$ & $\begin{array}{c}4 \\
15.38 \%\end{array}$ & $\begin{array}{c}3 \\
11.54 \%\end{array}$ & $\begin{array}{c}8 \\
30.77 \%\end{array}$ & $\begin{array}{c}11 \\
42.31 \%\end{array}$ & 26 \\
\hline b. & $\begin{array}{l}\text { assessment is based on student } \\
\text { performance }\end{array}$ & $\begin{array}{c}2 \\
7.69 \%\end{array}$ & $\begin{array}{c}6 \\
23.08 \%\end{array}$ & $\begin{array}{c}8 \\
30.77 \%\end{array}$ & $\begin{array}{c}10 \\
38.46 \%\end{array}$ & 26 \\
\hline C. & $\begin{array}{l}\text { assessment should promote } \\
\text { continuous and reflective processes }\end{array}$ & $\begin{array}{c}2 \\
7.69 \% \\
\end{array}$ & $\begin{array}{c}4 \\
15.38 \%\end{array}$ & $\begin{array}{c}14 \\
53.85 \%\end{array}$ & $\begin{array}{c}6 \\
23.08 \% \\
\end{array}$ & 26 \\
\hline d. & $\begin{array}{l}\text { teachers must use grades to } \\
\text { represent how much students have } \\
\text { learned }\end{array}$ & $\begin{array}{c}3 \\
11.54 \%\end{array}$ & $\begin{array}{c}5 \\
19.23 \%\end{array}$ & $\begin{array}{c}6 \\
23.08 \%\end{array}$ & $\begin{array}{c}12 \\
46.15 \%\end{array}$ & 26 \\
\hline e. & $\begin{array}{l}\text { assessment could be carried at } \\
\text { specific moments }\end{array}$ & $\begin{array}{c}3 \\
11.54 \%\end{array}$ & $\begin{array}{c}5 \\
19.23 \%\end{array}$ & $\begin{array}{c}8 \\
30.77 \%\end{array}$ & $\begin{array}{c}10 \\
38.46 \%\end{array}$ & 26 \\
\hline f. & $\begin{array}{l}\text { assessment is done only by the } \\
\text { teacher }\end{array}$ & $\begin{array}{c}4 \\
15.38 \%\end{array}$ & $\begin{array}{c}3 \\
11.54 \%\end{array}$ & $\begin{array}{c}12 \\
46.15 \%\end{array}$ & $\begin{array}{c}7 \\
26.93 \%\end{array}$ & 26 \\
\hline g. & $\begin{array}{llll}\begin{array}{l}\text { students } \\
\text { students }\end{array} & \text { could assess } & \text { other } \\
\end{array}$ & $\begin{array}{c}6 \\
23.08 \%\end{array}$ & $\begin{array}{c}10 \\
38.46 \%\end{array}$ & $\begin{array}{c}8 \\
30.77 \%\end{array}$ & $\begin{array}{c}2 \\
7.69 \%\end{array}$ & 26 \\
\hline h. & $\begin{array}{l}\text { assessment determines if students } \\
\text { meet the language standards }\end{array}$ & $\begin{array}{c}2 \\
7.69 \%\end{array}$ & $\begin{array}{c}2 \\
7.69 \%\end{array}$ & $\begin{array}{c}12 \\
46.15 \%\end{array}$ & $\begin{array}{c}10 \\
38.47 \%\end{array}$ & 26 \\
\hline
\end{tabular}

Source: compiled by the author based on data gathered through Master of TESOL students' answers, 2020

Table 5 shows that for statement $14 a$, considering the Very probably $(30.77 \%)$ and Definitely $(42.31 \%)$ categories, the majority of respondents indicated that "assessment must be developed according to the educational institution's curriculum". While a minority of respondents (7.69\%) stated that assessment was not based on student performance (14b), 38.46 per cent said it was. Over 70 per cent of respondents said Very probably or Definitely to the statement "assessment should promote continuous and reflective processes" (14c), whereas less than 30 per cent said Definitely not or Probably not. The categories Very probably and Definitely accounted for 69.23 per cent of responses to statement 14d: "teachers must use grades to represent how much students have learned"; whereas a minority said Definitely not (11.54\%) or Probably not (19.23\%).

For statement 14e: "assessment could be carried at specific moments", the categories of Very probably and Definitely represented a strong majority of responses $(30.77 \%$ and $38.46 \%$ respectively). Likewise, more than 70 per cent of respondents said Very probably or Definitely 
to the statement "assessment is done only by the teacher" (14f) (46.15\%; $26.92 \%$ respectively). Combined, the categories Definitely not and Probably not (23.08\%; 38.46\% respectively), indicated that the majority of respondents (61.54\%) were not in favour of students assessing other students (14g). The Very probably and Definitely categories accounted for over 80 per cent of responses to the statement "assessment determines if students meet the language standards" (14h).

\subsection{Assessment forms}

Question 15 (Table 6) examined the respondents' frequency of use of different assessment forms. The level of agreement of respondents with these statements is presented through frequencies and percentages.

Table 6

Melbourne, Australia: frequency and percentages of students' use of assessment forms. 2020

\begin{tabular}{|c|l|c|c|c|c|c|}
\hline Q15 & \multicolumn{1}{|c|}{ Item } & Never & $\begin{array}{c}\text { Very } \\
\text { rarely }\end{array}$ & $\begin{array}{c}\text { Very } \\
\text { frequently }\end{array}$ & Always & Total \\
\hline a. & Paper-based tests/quizzes & 0 & 3 & 16 & 7 & 26 \\
& & $0.00 \%$ & $11.54 \%$ & $61.54 \%$ & $26.92 \%$ & \\
\hline b. & National standardized test samples & 0 & 7 & 16 & 3 & 26 \\
& & $0.00 \%$ & $26.92 \%$ & $61.54 \%$ & $11.54 \%$ & \\
\hline c. & Dictation & 2 & 9 & 12 & 3 & 26 \\
& & $7.69 \%$ & $34.62 \%$ & $46.15 \%$ & $11.54 \%$ & \\
\hline d. & Essays & 2 & 11 & 11 & 2 & 26 \\
\hline e. & Presentations & $7.69 \%$ & $42.31 \%$ & $42.31 \%$ & $7.69 \%$ & \\
\hline f. & Games & 2 & 11 & 10 & 3 & 26 \\
& & $7.69 \%$ & $42.31 \%$ & $38.46 \%$ & $11.54 \%$ & \\
\hline
\end{tabular}

Source: compiled by the author based on data gathered through Master of TESOL students' answers, 2020

As shown in Table 6, the majority of respondents said they used devices such as "paperbased tests/quizzes" (15a), with a high number of responses to the category of Very frequently (61.54\%), and over one quarter (26.92\%) indicating Always. The percentage of respondents in the Very frequently category was the same for $15 \mathrm{a}$ and $15 \mathrm{~b}$, with 61.54 per cent indicating they used "national standardized test samples" Very frequently. Nearly half of the respondents $(46.15 \%)$ said they Very frequently implemented "dictation" (15c) as an assessment form. Essays (15d) were used Very rarely and Very Frequently by the same percentage of respondents (42.31\%). Similar percentages were also reflected in the Never and Always categories $(7.69 \%$ each). These results indicated that half of the respondents said they are inclined to use essays, while the other half is not. 
Table 6 shows that half of the respondents said they use "presentations" (15e) less frequently, as represented by the Never or Very rarely categories (7.69\%; $42.31 \%$ respectively). Likewise, 50 per cent of respondents said they use "presentations" (15e) Very frequently or Always (38.46\%; 11.54\% respectively). Combined, the categories of Never and Very rarely represented over 50 per cent of the responses to the use of games (15f) as a form of assessment, while the categories of Very frequently and Always represented 42.3 per cent of responses.

\subsection{Discussions}

The findings demonstrated that the participants who grasped assessment from formative views, focused their answers on language learning processes and performance, while those who favoured summative practices focused their answers on the linguistic knowledge and language level. The frequency in Table 3 showed, for instance, that Master of TESOL students were inclined towards summative assessment than to formative. This is aligned with the study done by Brown et al. (2011) which revealed that teachers' conceptions of assessment dealt with two things, improving teaching and learning, and making schools, teachers and students accountable.

In general, Master of TESOL students had a tendency to conceive assessment as a means to know how much students have learned by the use of traditional forms of assessment. Such understandings are potentially influenced by the students' backgrounds and contexts. Most of the participants in the study come from countries where summative assessment seems to be favoured in educational policies and among the educational community, such as Colombia, China, India, Nepal, Pakistan, Sir Lanka or Vietnam. This result can be linked to the research conducted by Azis (2012), Brown, Hui, Yu \& Kennedy (2011), Brown et al. (2011), Brown \& Remesal (2017) and Gebril (2017), who established a causal relation between the language policies and contextual aspects that circumscribe teachers and their conceptions of assessment.

Even though most of the Master of TESOL students involved in the study considered the purposes and principles from a formative assessment perspective, in their understandings and practices of assessment, the majority had a tendency to exclude students' participation in the assessment process. This finding might show that the participants focused their assessment understandings on the leading role of teachers and on what is stated in the syllabus. This view is opposed to assessment theories developed by scholars such as Feng (2019), Earl \& Giles 
(2011) and Lamb \& Litle (2016), Masters (2013), who have consistently advocated for assessment as a process that empowers students to reflect on their own learning process and become autonomous learners, by giving them the opportunity to participate in the design and development of assessment.

\subsection{Recommendations}

The results of this study might open further discussions on the field of assessment and help as a point of reference to examine how English teachers' conceptions of assessment can potentially impact teaching and learning processes. Considering that respondents reported tendencies to summative assessment in their understandings of assessment as a process, its forms and types, the ideas exposed in this study could be transferred to relevant contexts and serve to reflect on how teaching training courses might promote the learning of student assessment more centred on formative assessment features. In accordance with Broadbent, Panadero and Boud (2018), Purpura (2016) and Scarino (2017), education, including language learning, should emphasise formative assessment in the learning process since it is focused on the students' needs, progress, improvement and context, so it can provide scaffolded learning and more meaningful learning experiences. Therefore, the relevance of considering formative assessment as an essential part of teachers' training lies on the necessity that teachers develop the necessary knowledge and skills to favour students' learning, improvement and autonomy rather than products, results and marks (Broadbent et al., 2018; Purpura, 2016).

\subsection{Limitations}

There were some limitations and potential issues in this study. we intended to invite Master of TESOL students to participate in the online questionnaire by visiting face-to-face classes. The purpose was to inform them of the study and general aspects of the questionnaire. Due to a worldwide health emergency, the University moved to online teaching. Therefore, the call for participants had to be mediated through the Learning Management System (LMS) of each subject, which might have affected its impact, response rate and sample size. Likewise, the current health pandemic might have affected the interest and involvement of those who decided to participate. The sample size was small (26 respondents), so results are not generalisable to other contexts and subjects. 


\section{Conclusions}

The findings show that due to language training and teaching experience in English language teaching and learning, these Master of TESOL students favour two conceptions of student assessment, summative and formative, but in their understandings, they show some contradictions. Furthermore, according to their learning and teaching background at different educational levels, the majority of the Master of TESOL students consider student assessment is important for teaching; nonetheless, half of them affirm they have not received any training on student assessment throughout their studies. This lack of knowledge on the theory of assessment combined with their learning and teaching experience may guide them to express different ideas of it. For instance, they all understand assessment as a method but not all of them agree with its intentions. For most of them it was to test, measure, and evaluate; for a very small part of them, it was to report, improve and promote.

In their views of student assessment, they also show a contradiction between their conceptions and the ones suggested by the literature. Despite their interest in measuring and their tendency to summative assessment, they show a disagreement level on the use of written tests, exams and quizzes. Contrasting their views of assessment and assessment purposes, the findings denote that they are tuned with the use of summative assessment, in this case, the assessment of the language; nevertheless, the findings also show that they have a tendency for assessment for and in the learning of a language, which are aims of formative assessment. Half of the participants believe self-assessment practices should not be considered as a part of student assessment; however, in their teaching background, the approach they seem to favour the most was the Communicative one.

Another inconsistency indicated by the findings show that the Master of TESOL students, based on the assessment principles, had a high percentage of agreement related to formative assessment. Nevertheless, this is opposite to what they have stated in their understandings of assessment, and the assessment types and forms. Talking about the types and forms of assessment, the findings indicate again that they have a tendency to use summative assessment techniques and instruments. They are inclined to use grades that take place at specific moments and are controlled by the teacher. In this vein, the findings also suggest that student assessment is no longer a continuous process and it is unidirectional, reducing the use of alternative instruments like presentations, games or any other that suits this kind of forms.

According to the findings aforementioned, it could be said that this group of Master of TESOL students do not have significantly different conceptions of student assessment, since 
their views aim at two types of perspectives, summative and formative assessment, being summative the one that has more acceptability. However, the results also show that there are misinterpretations among the purposes, principles, types and forms of assessment, which may cause the contradictions found in this study.

\section{References}

Álvarez, Juan. (2008). Evaluar para conocer, examinar para excluir. Madrid: Morata.

Assessment Reform Group. (2002). Assessment for Learning: 10 research-based principles to guide classroom practice. Retrieved from https://www.aaia.org.uk/storage/medialibrary/o 1d8j89n3u1n0u17u91fdd1m4418fh8.p $\underline{\mathrm{df}}$

Azis, Astuti. (2012). Teachers' conceptions and use of assessment in student learning. Indonesian Journal of Applied Linguistics, 2(1), 40-52. doi: https://doi.org/10.17509/ijal.v2i1.72

Bachman, Lyle., \& Palmer, Adrian. (2010). Language assessment in practice: Developing language assessments and justifying their use in the real world. Oxford, United Kingdom: Oxford University Press.

Barnes, Nicole., Fives, Helen., \& Dacey, Charity. (2017). U.S. teachers' conceptions of the purposes of assessment. Teaching and Teacher Education, 65, 107-116. doi: https://doi.org/10.1016/..tate.2017.02.017

Bennett, Randy. (2010). Cognitively based assessment of, for, and as learning (CBAL): a preliminary theory of action for summative and formative assessment. Measurement: Interdisciplinary Research and Perspectives, 8(2-3), 70-91. doi: https://doi.org/10.1080/15366367.2010.508686

Black, Paul., \& Wiliam, Dylan. (2006). Assessment for learning in the classroom. In J. Gardner (Ed.), Assessment and learning (pp. 9-25). London, United Kingdom: Sage Publications Ltd.

Black, Paul., \& Wiliam, Dylan. (2010). Inside the black box: Raising standards through classroom assessment. Phi Delta Kappan, 92(1), 81-90. doi: https://doi.org/10.1177\%2F003172171009200119

Brindley, Geoff. (2001). Language assessment and professional development. In C. Elder, A. Brown, K. Hill, N. Iwashita, T. Lumley, T. McNamara, \& K. O'Loughlin (Eds.), Experimenting with uncertainty: Essays in honour of Alan Davies (pp. 126136). Cambridge, United Kingdom: Cambridge University Press.

Broadbent, Jaclyn., Panadero, Ernesto., \& Boud, David. (2018). Implementing summative assessment with a formative flavour: A case study in a large class. Assessment \& Evaluation in Higher Education, 43(2), 307-322. doi: https://doi.org/10.1080/02602938.2017.1343455 
Brown, Douglas., \& Abeywickrama, Priyanvada. (2019). Language Assessment: Principles and Classroom Practices ( $3^{\text {rd }}$ ed.). Hoboken, United States of America: Pearson Education.

Brown, Gavin., Lake, Robert., \& Matters, Gabrielle. (2011). Queensland teachers' conceptions of assessment: The impact of policy priorities on teacher attitudes. Teaching and Teacher Education, 27(1), 210-220. doi: https://doi.org/10.1016/j.tate.2010.08.003

Brown, Gavin. (2008). Conceptions of assessment: Understanding what assessment means to teachers and students. New York, United States of America: Nova Science Publishers.

Brown, Gavin., Hui, Sammy., Yu, Flora., \& Kennedy, Kerry. (2011). Teachers' conceptions of assessment in Chinese contexts: A tripartite model of accountability, improvement, and irrelevance. International Journal of Educational Research, 50(5-6), 307-320. doi: $\underline{\text { https://doi.org/10.1016/j.ijer.2011.10.003 }}$

Brown, Gavin., Lake, Robert., \& Matters, Gabrielle. (2011). Queensland teachers' conceptions of assessment: The impact of policy priorities on teacher attitudes. Teaching and Teacher Education, 27(1), 210-220. Retrieved from https://www.redalyc.org/pdf/172/17223141008.pdf

Brown, Gavin., \& Remesal, Ana. (2012). Prospective teachers' conceptions of assessment: A cross-cultural comparison. The Spanish Journal of Psychology, 15(1), 75-89. doi: https://doi.org/10.5209/revsjop.2012.v15.n1.37286

Brown, Gavin., \& Remesal, Ana. (2017). Teachers' conceptions of assessment: Comparing two inventories with Ecuadorian teachers. Studies in Educational Evaluation, 55, 68-74. doi: https://doi.org/10.1016/i.stueduc.2017.07.003

Case, Jennifer. (2015). Emergent interactions: Rethinking the relationship between teaching and learning. Teaching in Higher Education, 20(6), 625-635. doi: https://doi.org/10.1080/13562517.2015.1052787

Cheng, Liying., \& Fox, Janna. (2017). Assessment in the language classroom. London, United Kingdom: Palgrave Macmillan.

Cohen, Louis., Manion, Lawrence., \& Morrison, Keith. (2018). Research methods in education ( $8^{\text {th }}$ ed.). London, United Kingdom: Routledge.

Cornelius, Kyena. (2014). Formative assessment made easy: Templates for collecting daily data in inclusive classrooms. Teaching Exceptional Children, 47(2), 112 - 118. doi: https://doi.org/10.1177/0040059914553204

Council of Europe. (2001). Common European framework of reference for languages: Learning, teaching, assessment. Cambridge, United Kingdom: Cambridge University Press.

Creswell, John. (2018). Educational research: Planning, conducting, and evaluating quantitative and qualitative research ( $6^{\text {th }}$ ed.). New Jersey, United States of America: Pearson. 
De Leeuw, Edith.,, Hox, Joop., \& Dillman, Don. (2008). International handbook of survey methodology. London, United Kingdom: Routledge.

DeLuca, Christopher., LaPointe-McEwan, Danielle., \& Luhanga, Ulemu. (2016). Teacher assessment literacy: A review of international standards and measures. Educational Assessment, Evaluation and Accountability, 28(3), 251-272. doi: https://doi.org/10.1007/s11092-015-9233-6

Dixson, Dante., \& Worrell, Frank. (2016). Formative and summative assessment in the classroom. Theory into practice, 55(2), 153-159. doi: https://doi.org/10.1080/00405841.2016.1148989

Earl, Kerry., \& Giles, David. (2011). An-other look at assessment: assessment in learning. New Zealand Journal of Teachers' Work, 8(1), 11-20. Retrieved from https://hdl.handle.net/10289/5766

Earl, Lorna. (2013). Assessment as learning: Using classroom assessment to maximize student learning ( $2^{\text {nd }}$ ed.). California, United States of America: Thousand Oaks.

Everhard, Carol., \& Murphy, Linda. (2015). Assessment and autonomy in language learning. London, United Kingdom: Palgrave Macmillan.

Frank, Jerrold. (2012). The role of assessment in language teaching. English Teaching Forum, 50(3). Retrieved from https://files.eric.ed.gov/fulltext/EJ997527.pdf

Feng, Teng. (2019). Autonomy, agency, and identity in teaching and learning English as a foreign language. Singapore: Springer.

Fowler, Floyd. (2014). Survey research methods ( $5^{\text {th }}$ ed.). London, United Kingdom: SAGE.

Gebril, Atta. (2017). Language teachers' conceptions of assessment: An Egyptian perspective, teacher development, 21(1), 81-100. doi: https://doi.org/10.1080/13664530.2016.1218364

Jorba, Jaume., \& Sanmartí, Neus. (2000). La función pedagógica de la evaluación. In M. Ballester, J.M. Batalloso, M. Calatayud, I. Córdoba, J. Diego, \& M. Fons (Eds.). Evaluación como ayuda al aprendizaje (pp. 21-44). Madrid, España: Graó-Editorial.

Lamb, Terry., \& Little, Sabine. (2016). Assessment for autonomy, assessment for learning, and learner motivation: Fostering learner identities. In D. Tsagari (ed.), Classroom-based assessment in L2 contexts (pp. 184-206). Cambridge, United Kingdom: Cambridge Scholars Publishing.

Leung, Constant., \& Lewkowicz, Jo. (2017). Assessing second/additional language of diverse populations. In E. Shohamy \& I. May (Eds.), Language Testing and Assessment (3 ${ }^{\text {rd }}$ ed.) (pp. 323-342). Cham: Springer.

Macalister, John., \& Nation, Paul. (2011). Case Studies in Language Curriculum Design: Concepts and Approaches in Action Around the World. New York: Routledge. 
Masters, Geoff. (2013). Reforming education assessment: Imperatives, principles and challenges. Camberwell, London : Australian Council for Educational Research.

McNamara, Tim., \& Roever, Carsten. (2006). Language testing: The social dimension. Malden, United States of America: Blackwell Publishing.

Murphy, Linda. (2015). Autonomy in assessment: Bridging the gap between rhetoric and reality in a distance language learning. In C. Everhard \& L. Murphy (Eds.), Assessment and autonomy in language learning (pp. 8-34). London, United Kingdom: Palgrave Macmillan.

Opre, Dana. (2015). Teachers' conceptions of assessment. Procedia-Social and Behavioral Sciences, 209(3), 229-233. doi: https://doi.org/10.1016/i.sbspro.2015.11.222

Purpura, James. (2016). Second and foreign language assessment. Modern Language Journal, 100(S1), 190-208. doi: https://doi.org/10.1111/modl.12308

Richards, Jack., \& Rodgers, Theodore. (2015). Approaches and methods in language teaching ( $3^{\text {rd }}$ ed.). Cambridg, United Kingdom: Cambridge University Press.

Roever, Carsten. (2011). Testing of second language pragmatics: Past and future. Language Testing, 28(4), 463-481. doi: https://doi.org/10.1177/0265532210394633

Scarino, Angela. (2013). Language assessment literacy as self-awareness: Understanding the role of interpretation in assessment and in teacher learning. Language Testing, 30(3), 309-27. doi: https://doi.org/10.1177/0265532213480128

Scarino, Angela. (2017). Developing assessment literacy of teachers of languages: A conceptual and interpretive challenge. Papers in Language Testing and Assessment, 6(1), 18-40. Retrieved from https://arts.unimelb.edu.au/ data/assets/pdf file/0008/2349863/6 1 SI2Scarino.pdf

Shohamy, Elana. (2007). Language tests as language policy tools. Assessment in Education: Principles, Policy \& Practice, 14(1), 117-130. doi: https://doi.org/10.1080/09695940701272948

Taras, Maddalena. (2005). Assessment - summative and formative - some theoretical reflections. British Journal of Educational Studies, 53(4), 466-478. doi: https://doi.org/10.1111/i.1467-8527.2005.00307.x

Tsagari, Dina., Vogt, Karin., Froelich, Veronika., Csépes, Ildikó., Fekete, Adrienne., Green Anthony., Hamp-Lyons, Liz., Sifakis, Nicos., \& Kordia, Stefania. (2018). Handbook of assessment for language teachers. Retrieved from https://taleproject.eu/mod/page/view.php?id=1200 


\section{Appendix A: Online questionnaire}

Teachers' conceptions of student assessment in English Language teaching: the case of Master of TESOL students at a university in Australia

\section{A Background information}

These questions are about you, your educational and teaching background, and your involvement with student assessment.

1. What is your gender?

2. What is the highest educational qualification you have completed? (e.g., Bachelor, Major in Education, Colombia)

- Bachelor $\square$ Major in

- Masters $\quad \square$ Major in

- Doctorate $\square$ Major in Country Country Country

3. Do you have previous experience teaching English? Yes No

If the answer is no, please go to question 8

4. It what educational contexts have you taught English? (Mark all that apply)

\begin{tabular}{ccccc}
\hline Preschool & Primary & Secondary & Higher & Language \\
$\square$ & $\square$ & $\square$ & $\square$ & centres \\
\hline
\end{tabular}

5. For how many years have you taught English?

\begin{tabular}{cccc}
\hline $1-5$ & $6-10$ & $10+$ & Other \\
$\square$ & $\square$ & $\square$ & \\
\hline
\end{tabular}

6. Have you taught English ... (Mark all that apply)

\begin{tabular}{|c|c|c|c|}
\hline $\begin{array}{c}\text { as a Foreign } \\
\text { language (EFL) }\end{array}$ & $\begin{array}{c}\text { as a Second } \\
\text { Language (ESL) }\end{array}$ & $\begin{array}{l}\text { as an Additional } \\
\text { Language (EAL) }\end{array}$ & $\begin{array}{c}\text { for Specific } \\
\text { Purposes (ESP) }\end{array}$ \\
\hline $\begin{array}{l}\text { English is usually } \\
\text { learned and taught in } \\
\text { environments where } \\
\text { it is not the language } \\
\text { of the community nor } \\
\text { the school. }\end{array}$ & $\begin{array}{l}\text { English is learned } \\
\text { and taught in } \\
\text { environments where } \\
\text { it is the language of } \\
\text { the community and } \\
\text { the school. }\end{array}$ & $\begin{array}{l}\text { Students are already } \\
\text { competent speakers } \\
\text { of at least one home } \\
\text { language. }\end{array}$ & $\begin{array}{l}\text { English is learned } \\
\text { and taught } \\
\text { according to the } \\
\text { learner's reason for } \\
\text { learning. }\end{array}$ \\
\hline
\end{tabular}

7. Please write down the name of the most common language teaching approach you use in your classes 
8. During your academic studies, have you been enrolled in a subject where you were taught how to assess students?

Yes No

9. In your opinion, how important do you consider student assessment is for language teaching? (Please mark one choice)

\begin{tabular}{cccc}
\hline Not important & Slightly important & Important & Very important \\
$\square_{1}$ & $\square_{2}$ & $\square_{3}$ & $\square_{4}$ \\
\hline
\end{tabular}

\section{B. Conception of assessment}

This part asks about your beliefs and conceptions about student assessment, whatever this means to you. Please answer the questions using your own understanding and practices of assessment.

10. In your own words, please describe what you understand by student assessment.

11. In your own understanding and comprehension of student assessment, to what extent do you agree or disagree with the following statements? (Please mark one choice in each row)

In your view,

Strongl

$y$

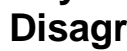

ee

a. assessment provides information on how much students have learnt

b. assessment must be done daily

c. assessment must be done through written tests, exams, quizzes, etc.

d. assessment must be done through portfolios, journals, presentations, journals, etc.

e. assessment must be done only by the teacher

f. assessment must be reported to students orally

g. assessment must be reported to students in a written way

h. numbers and/or letters can represent how much students know about the language

i. assessment helps students to improve their language learning strategies and skills

$\begin{array}{llcc}\square_{1} & \square_{2} & \square_{3} & \square_{4} \\ \square_{1} & \square_{2} & \square_{3} & \square_{4} \\ \square_{1} & \square_{2} & \square_{3} & \square_{4} \\ \square_{1} & \square_{2} & \square_{3} & \square_{4} \\ \square_{1} & \square_{2} & \square_{3} & \square_{4} \\ \square_{1} & \square_{2} & \square_{3} & \square_{4} \\ \square_{1} & \square_{2} & \square_{3} & \square_{4} \\ \square_{1} & \square_{2} & \square_{3} & \square_{4} \\ \square_{1} & \square_{2} & \square_{3} & \square_{4}\end{array}$




\section{Purposes of assessment}

This part asks about the purposes student assessment has in relation to English language teaching.

12. Regarding your understanding of assessment purposes, to what extent do you agree or disagree with the following statements? (Please mark one choice in each row)

\begin{tabular}{|c|c|c|c|c|}
\hline In your view, & $\begin{array}{l}\text { Strongly } \\
\text { Disagree }\end{array}$ & Disagree & Agree & $\begin{array}{l}\text { Strongly } \\
\text { Agree }\end{array}$ \\
\hline $\begin{array}{l}\text { a. assessment outcomes can help students } \\
\text { to improve their language level }\end{array}$ & $\square_{1}$ & $\square_{2}$ & $\square_{4}$ & $\square_{5}$ \\
\hline $\begin{array}{l}\text { b. self-assessment is a complementary part } \\
\text { of Student assessment }\end{array}$ & $\square_{1}$ & $\square_{2}$ & $\square_{4}$ & $\square_{5}$ \\
\hline $\begin{array}{l}\text { c. assessment must be a process to gather } \\
\text { information about students' learning } \\
\text { achievements }\end{array}$ & $\square_{1}$ & $\square_{2}$ & $\square 4$ & $\square_{5}$ \\
\hline $\begin{array}{l}\text { d. assessment must integrate the language } \\
\text { learning and teaching processes }\end{array}$ & $\square_{1}$ & $\square_{2}$ & $\square_{4}$ & $\square_{5}$ \\
\hline
\end{tabular}

\section{Principles of assessment}

This part asks about assessment principles and their relation to English language teaching.

13. Regarding your understanding of student assessment principles, to what extent do you agree or disagree with the following statements? (Please mark one choice in each row)

\begin{tabular}{|c|c|c|c|c|}
\hline In your view, & $\begin{array}{l}\text { Strongly } \\
\text { Disagree }\end{array}$ & Disagree & Agree & $\begin{array}{l}\text { Strongly } \\
\text { Agree }\end{array}$ \\
\hline $\begin{array}{l}\text { a. assessment must be done through } \\
\text { problem solving activities }\end{array}$ & $\square_{1}$ & $\square_{2}$ & $\square 3$ & $\square_{4}$ \\
\hline $\begin{array}{l}\text { b. assessment works as a teaching strategy } \\
\text { planned in the syllabus }\end{array}$ & $\square_{1}$ & $\square_{2}$ & $\square_{4}$ & $\square 5$ \\
\hline $\begin{array}{l}\text { c. assessment has an impact on students' } \\
\text { learning motivation }\end{array}$ & $\square_{1}$ & $\square_{2}$ & $\square_{4}$ & $\square_{5}$ \\
\hline $\begin{array}{l}\text { d. teachers must make explicit the } \\
\text { assessment objectives throughout the } \\
\text { subject }\end{array}$ & $\square_{1}$ & $\square_{2}$ & $\square_{4}$ & $\square 5$ \\
\hline $\begin{array}{l}\text { e. students must participate in the design of } \\
\text { the assessment process in every subject }\end{array}$ & $\square_{1}$ & $\square_{2}$ & $\square_{4}$ & $\square 5$ \\
\hline
\end{tabular}

\section{E Types of assessment}

This part asks about the types of assessment and their relation with the purposes and principles of assessment.

14. Regarding your understanding of student assessment types, to what extent do you agree or disagree with the following statements? (Please mark one choice in each row) 


\begin{tabular}{|c|c|c|c|c|}
\hline In your experience, & $\begin{array}{c}\text { Definitely } \\
\text { Not }\end{array}$ & $\begin{array}{c}\text { Probably } \\
\text { Not }\end{array}$ & $\begin{array}{c}\text { Very } \\
\text { Probably }\end{array}$ & Definitely \\
\hline $\begin{array}{l}\text { a. assessment must be developed } \\
\text { according to the educational institution's } \\
\text { curriculum }\end{array}$ & $\square_{1}$ & $\square_{2}$ & $\square_{3}$ & $\square_{4}$ \\
\hline $\begin{array}{l}\text { b. assessment is based on student } \\
\text { performance }\end{array}$ & $\square_{1}$ & $\square_{2}$ & $\square_{4}$ & $\square_{5}$ \\
\hline $\begin{array}{l}\text { c. assessment should promote } \\
\text { continuous and reflective processes }\end{array}$ & $\square_{1}$ & $\square_{2}$ & $\square_{4}$ & $\square_{5}$ \\
\hline $\begin{array}{l}\text { d. teachers must use grades to represent } \\
\text { how much students have learnt }\end{array}$ & $\square_{1}$ & $\square_{2}$ & $\square_{4}$ & $\square_{5}$ \\
\hline $\begin{array}{l}\text { e. student assessment could be carried } \\
\text { at specific moments }\end{array}$ & $\square_{1}$ & $\square_{2}$ & $\square_{4}$ & $\square_{5}$ \\
\hline f. assessment is done only by the teacher & $\square_{1}$ & $\square_{2}$ & $\square_{4}$ & $\square_{5}$ \\
\hline g. students could assess other students & $\square_{1}$ & $\square_{2}$ & $\square_{4}$ & $\square_{5}$ \\
\hline $\begin{array}{l}\text { h. assessment determines if students } \\
\text { meet the language standards }\end{array}$ & $\square_{1}$ & $\square_{2}$ & $\square_{4}$ & $\square 5$ \\
\hline
\end{tabular}

\section{F. Forms of assessment}

This part asks about the forms of assessment and their relation with the purposes, principles and types of assessment.

15. In your own experience, when you teach, how often do you use these assessing devices (Please mark one choice in each row)

In your experience,

a. Paper-based tests/quizzes

b. National standardized test samples

c. Dictation

d. Essays

e. Presentations

f. Games
Very Very

Never Rarely Frequently Always 


\section{Revista indizada en}
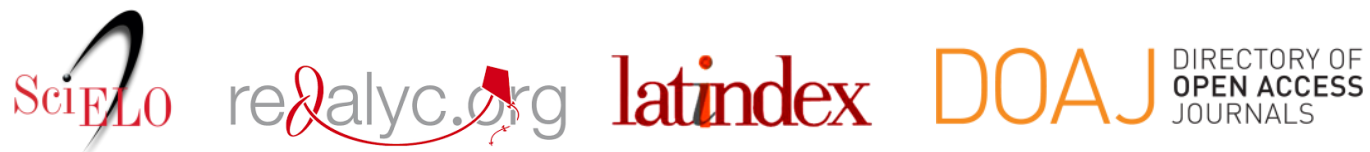

Distribuida en las bases de datos:
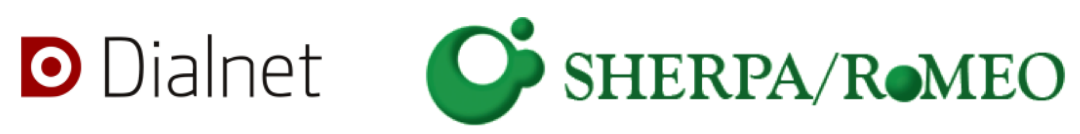

REDIB

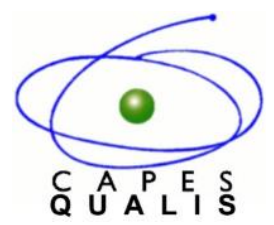

MIAR 